The Journal of Animal \& Plant Sciences, 31(4): 2021, Page: 929-936

ISSN (print): 1018-7081; ISSN (online): 2309-8694

\title{
SILAGE FERMENTATION AND CHEMICAL COMPOSITION OF CHAMAECITYSUS PROLIFERUS VAR PALMENSIS (TAGASASTE) AND PENNISETUM SP (MARALFALFA) USING DIFFERENT ADDITIVES
}

\author{
S. Álvarez ${ }^{1}$, P. Méndez and A. Martínez-Fernández ${ }^{2}$ \\ ${ }^{1}$ Unit of Animal Production, Pasture and Forage in Arid and Subtropical Areas. Canary Islands Institute for Agricultural \\ Research (ICIA), Tenerife, Spain \\ ${ }^{2}$ Department of Animal Nutrition, Grassland and Forages.Regional Institute of Research and Agro-Food Development \\ (SERIDA), Asturias, Spain \\ Corresponding author’s email: salvarez@icia.es
}

\begin{abstract}
The aim of this study was to evaluate the fermentation characteristics and nutritive value of two interesting forage species (maralfalfa and tagasaste) ensiled with molasses and beet pulp as additives. Ensilability parameters and chemical composition were analysed in two different stages of growth in maralfalfa (flowering and vegetative growing) and two different branch diameters in tagasaste (branches $>5 \mathrm{~mm}$, branches $\leq 5 \mathrm{~mm}$ ). According to ensilability results, four combinations with additives (two for tagasaste and two for maralfalfa) were ensiled at laboratory scale microsilos, in order to evaluate fermentative and nutritive parameters in two different conservation periods (35d and 70d). Tagasaste showed high dry matter (DM) content and fermentability ratio (FR) but a very low sugar content (WSC). Maralfalfa showed poor initial ensiling characteristics, low DM and WSC and high BC (buffering capacity). Supplementing tagasaste with molasses improves the fermentative composition in mini-silos with adequate ammonia- $\mathrm{N}$ and lactic acid concentrations detected. Moreover, the addition of beet pulp and molasses to the ensiled maralfalfa allows achieving the $\mathrm{pH}$ value under 4 and NH3-N content below $10 \%$, with an interesting content of lactic acid improving the fermentation quality of silage.
\end{abstract}

Keywords: Ensilability characteristics; fermentation quality; forage grass; legume; silage.

\section{INTRODUCTION}

Maralfalfa (Pennisetum sp) is a perennial tropical forage with excellent potential for dry matter yield per area cultivated and reasonable nutritive value. To be used as a silage it does not present appropriate characteristics due to its high moisture and low concentration of soluble carbohydrates that results in a poor-quality fermentation with great nutrients losses (Zanine et al., 2007). However, it is possible to obtain high quality silage when appropriate management is used, such as wilting and use of additives and/or agricultural by-products to preserve in good conditions the grass silage (Teles-Rego et al., 2010; Li et al., 2014).

Tagasaste (Chamaecitysus proliferus var palmensis) is an endemic shrub legume from the subhumid areas of the Canary Islands, fed usually as fresh and supplied through a cut and carry system, with a high nutritional value affecting positively goats' milk and cheese yield and quality (Álvarez et al., 2007; Álvarez et al., 2008). In experimental conditions with water supply is possible to obtain 3 cuts in 2 years in semiarid and warm areas (Méndez and Álvarez, 2014), however it has been observed not damage on the photosynthetic apparatus when subjected to progressive drought at the end of spring (González-Rodríguez et al., 2005). Since the late nineteenth century tagasaste has been introduced in other subhumid and semiarid zones of the world where is well adapted among other factors due to its deep root system (Heuzéet al., 2017). The preservation of forages as silage is applicable to diverse climatic zones in the world as a way to provide feed, as well as diet supplement to intensive livestock during a period of the year with yield scarcity and is one of the conservation techniques that better preserve the forage nutritional composition (Cowan, 2000). This technique is based in the conservation of forage produced during the wet season which can be fed to livestock kept in at least partially zero-grazing systems during the dry season. Tropical and subtropical grasses and legumes are not natural material for silage, largely because at harvest time, they have a low content of WSC, which are essential to successful in the ensilage process. However, these difficulties have been overcome widely nowadays by greater knowledge and control of factors causing difficulties for ensiling legumes (Albrecht and Beauchemin, 2003). In this sense, several studies on ensiled tropical legumes, both herbaceous and shrubs, showed satisfactory ensiled with the appropriate treatment, in order to overcome its difficulties. For instance, the use of silage additives is one of the practices to improve the levels of fermentable carbohydrates, reduce buffering and prevent proteolysis and can succeed in producing good 
quality silage. As well high variation in the treatment responses of the different forage should be considered (Heinritz et al., 2012).

Regarding the additives recommended for tropical forages, molasses has been widely used to provide fast fermentable carbohydrate for the ensilage of tropical herbages (Cao et al. 2010; Oni et al. 2014) and beet pulp along with other feed products has been used to modulate the fermentation process by absorbing excessive humidity. To avoid effluent losses is convenient to be used in high proportion and appropriately blended with the chopped forage. Besides, other additives have been used to improve the quality of tropical silages: citric pulp (Ferrari-Junior et al., 2009), jackfruit (Silva et al., 2011) or babassu meal (Rezende et al., 2011).

There are different objectives in using silage additives, the main target is to obtain a lactic acid fermentation that results in well preserved silage, preventing secondary fermentation and decreasing butyric acid production (McDonald et al., 1991). The effectiveness of additives depends on the degree of preventing such fermentation in silages (Aksu et al., 2004). Due to the possibility of silage preserved by these two species, capable to produce forage over a relating wide range of weather conditions, the present study assessed the chemical and fermentative characteristics of silage with addition of molasses and beet pulp as additives.

\section{MATERIALS AND METHODS}

Experimental design: The experiment was carried out at the Department of Animal Production, Forages and Pastures at the Canarian Agronomic Research Institute in La Laguna, Canary Islands (Spain). The center is situated at $28^{\circ}$ and $31^{\prime}$ latitude north and $16^{\circ}$ and $22^{\prime}$ longitude east and at $350 \mathrm{~m}$ altitude above sea level, with 300-400 mean annual rainfall, $90 \%$ of which falls from October to April, where tagasaste and maralfalfa are established as forage crops for the feeding of the experimental goats. In order to carry out the experimental silos, the phenological status of both crops and the thickness of the branches in the case of tagasaste were taken into account.

Two phenological stages of Maralfalfa (Maralfalfa at flowering stage, MF and Maralfalfa at vegetative growth stage, MV) and two types of branches of Tagasaste (Tagasaste including branches $>5 \mathrm{~mm}$, TB and Tagasaste including branches $\leq 5 \mathrm{~mm}, \mathrm{~Tb}$ ) at preflowering or early flowering stages samples were used. Samples were randomly selected from experimental plots of maralfalfa and tagasaste of 0.1 ha each one. Once a year, after a standardizing cut, maralfalfa is fertilized with goat manure from the farm. This grass is usually harvested every 40 days. Maralfalfa samples were cut from the experimental plot and processed in a conventional forage chopper regulated to cut in $2-3 \mathrm{~cm}$ particles. Tagasaste is also fertilized with organic matter through manure application and it is harvested once or twice a year; tagasaste samples were harvested from the experimental plot cutting branches directly from the shrubs. The branches were cut using a big knife and then chopped in a stationary machine, selecting the two different diameters of samples.

Chemical analysis: Maralfalfa (MF and MV) and Tagasaste (TB and Tb) samples analyzed in duplicate for ensilability characteristics following the methodology described by Martínez-Fernández et al. (2013) for dry matter (DM), water soluble carbohydrates (WSC), buffering capacity (BC) and fermentability ratio (FR). Thus the chemical composition was determined after freezer dryer and milled samples through $1 \mathrm{~mm}$ sieve, for $\mathrm{DM}$, ash, organic matter $(\mathrm{OM})$ and crude protein $(\mathrm{CP})$ according AOAC (1984), and acid detergent fiber (ADF), neutral detergent fiber (NDF) and acid detergent lignin (ADL) according Van Soest et al. (1991), in vitro organic matter cellulose digestibility-(IVOMD) according (Riveros and Argamentería, 1987) and gross energy (GE) by combustion using a calorimeter bomb IKA 5000 (IKAWerkeGmHand Co. KG, Germany).

According the results obtained for ensilability characteristics, four combinations were selected for ensiling: two for tagasaste using $\mathrm{Tb}$ samples ( $\mathrm{Tb} 1$ and $\mathrm{Tb} 2$ ) and two for maralfalfa using MV samples (MV1 and MV2) in order to assess the quality and stability over time of the experimental forages microsilages. The additives used were: $\mathrm{Tb} 1$ : $23 \%$ molasses $(47 \%$ soluble carbohydrates); Tb2: 17\% molasses; MV1: $20 \%$ molasses and $10 \%$ beet pulp ( $10 \%$ moisture); MV2: $23 \%$ molasses and $13 \%$ beet pulp. All material was ensiled in laboratory silos made of PVC cylinders provided with bun valves to allow for gas losses, and glass containers to store the evacuated effluent. These laboratory silos have a capacity of $4 \mathrm{dm}^{3}$ and a forage density of $650 \mathrm{~kg} \mathrm{~m}^{-3}$, according to Martínez-Fernández et al. (2014).

Chemical composition and silage suitability was evaluated after 35 and 70 days of fermentation period. The containers were individually opened. Three samples were taken from the top, centre and bottom of each ensiled mass and were frozen at $-18^{\circ} \mathrm{C}$ until analysis. For each forage 4 treatments ( 2 additives $\times 2$ opening periods of minisilos) with 2 replicates were established. The chemical composition of the silages was determined as described above for forages before ensiling.

The fermentation process was evaluated from final metabolites in silage juice in the Animal Nutrition laboratory in SERIDA (Asturias) for $\mathrm{pH}$, ammonia-N, WSC, lactic acid and volatile fatty acids including acetic, propionic and butyric acids (VFAs). Ammonia-N was determined by distillation with $\mathrm{MgO}$ according Kjeldalh procedure. Lactic acid and volatile fatty acids analyses were performed by HPLC with a Water Alliance 2690 instrument equipped with a Waters 996 Photodiode Array 
Detector Module (Waters. Milford, Massachusetts) monitoring at $206 \mathrm{~nm}$ and drove by Millenium software. The juice extract was analyzed on a Shodex RSpak KC811 column (Waters) using a mobile phase with $0.025 \%$ phosphoric acid. Flow rate was $1.0 \mathrm{ml} \mathrm{min} \mathrm{m}^{-1}$ and column temperature for analyses was kept at $40^{\circ} \mathrm{C}$.

Statistical analysis: The software package SPSS version 15.0.1 (SPSS Inc. Chicago, IL) was used for statistical processing of the results. Analyses of variance were performed for comparing the fermentative and chemical values after different ensilage times. Posthoc multiple analyses by Tukey's test were used for chemical composition of forages with additives before ensiling.

\section{RESULTS AND DISCUSSION}

Ensilability characteristics of tagasaste and maralfalfa (legume and grass forage respectively) are shown in Table 1, nutritive characteristics of both forages without additives in Table 2 and nutritive characteristics before ensiling (with additives) in Table 3.

The extent and pattern of fermentation in the silo are influenced by many factors, but the main effects are those brought about by the crop itself, principally its dry matter content, buffering capacity, water-soluble carbohydrate (WSC) concentration, and nitrate content (Martínez-Fernández et al., 2014). Moreover, some difficulties were reported for ensiling tropical forages and legumes, attributed to their high buffering capacity and low concentration in water soluble carbohydrates with the risk of proteolysis and a butyric acid fermentation (Titterton and Bareeba, 2000).

According this fact, the sample of TB showed the best aptitude for ensiling (Table1): high DM content and fermentability ratio and low buffering capacity (BC), although sugar content (WSC) was very low as has been described by many authors on legumes (Albrecht and Beauchemin, 2003, Dunière et al., 2013; MartínezFernández et al., 2014). Tb fraction presents lower DM content and slightly higher BC and WSC concentrations as well as better nutritive value (Table 2). Despite the better initial quality to be ensiled of TB it was not selected due to it worse nutritive value. Note that the nutritional chemical parameters of tagasaste are variable within a range, depending on various factors like any fodder, but with the addition of the individual variation as a wild species (Álvarez et al., 2007; Méndez and Álvarez, 2014). In this case the samples are within the lower range of those parameters. Regarding the ensilability of maralfalfa (Table 1), MF showed DM and BC values within the required range for proper silage, also FR was higher and more appropriate value than MV, but WSC level was similarly low in both samples. MV showed values out of required range in all the ensiling parameters but as its nutritive value was better (Table 2), this fraction was chosen to undertake silages.

The chemical composition of tagasaste samples selected $(\mathrm{Tb}, \mathrm{Tb} 1, \mathrm{~Tb} 2)$ before ensiling is reported in Table 3. Tagasaste without additives $(\mathrm{Tb})$ showed lower DM, IVOMD and UFL levels $(p<0.05)$ and higher NDF than those with molasses added (Tb1 and Tb2), although OM and CP were not affected. In legumes, molasses should be applied in relatively high concentrations resulting in a considerable effluent during the first days of silage with high additive losses (Henderson, 1993). In tagasaste this fact should not occur because the tagasaste DM content exceeded $35 \%$, adequate for ensiling. For this reason, in our case, molasses was added in two concentrations $(23 \%$ and $17 \%$ ) in order to increase WSC to optimum content. The chemical composition of maralfalfa selected (MV, MV1, MV2) before ensiling is given in Table 3. MV1 and MV2 showed higher DM content than maralfalfa without additives (MV) because of the addition of dehydrated beet pulp (10\% moisture).

At least $30 \%$ of DM is necessary to ensure a good response of the starting material to the silage process. Below this ratio, high volume of effluent can be generated, which results in an environmental problem and enable nutrient losses. Such wet material promotes the clostridial bacteria activity intensifying the production of butyric acid and finally reducing silage quality (Ashbell and Weinberg, 2000).Besides, the inclusion of beet pulp improved CP value nearly 4 points of percentage. Moreover, molasses addition (20-23\%) not only increased WSC content but also energy and IVOMD values by decreasing fiber (NDF and ADF) fractions $(p<0.05)$.

Table 4 contains the chemical and fermentative composition of two combinations of tagasaste with additives ( $\mathrm{Tb} 1, \mathrm{~Tb} 2)$ for two periods (35 and 70 days after ensiling). $\mathrm{Tb} 1$ and $\mathrm{Tb} 2$ showed a good aptitude for ensiling, and the end-product had a pleasant smell and good visual characteristics, except Tb2 in the 70 days sample that showed a slightly butyric odor due to the presence of small concentrations of butyric acid. The $\mathrm{pH}$ did not vary significantly among 35 and 70 days of ensiling, reaching values very close to 4 . Furthermore, the different concentrations of molasses added did not vary the final $\mathrm{pH}$ values in $\mathrm{Tb} 1$ and $\mathrm{Tb} 2$ combinations. These values are within the range of well-preserved silages allowing the inhibition of clostridia. (McDonald et al. 1991).

Ammonia-N concentrations are within the range recommended by INRA (1981) for adequate protein degradation during fermentation process. Degradation of plant protein during ensiling is inevitable and results in changes in the $\mathrm{N}$ constituents of ensiled herbage which reduce the nutritive value of the crude protein in the ensiled crop compared with fresh herbage (Rooke and Hatfield, 2003). Adequate amounts of lactic acid were detected in tagasaste mini-silos, with significant 
differences between $\mathrm{Tb} 1$ and $\mathrm{Tb} 2$ samples $(p<0.05)$ at 30 days of ensiling.

The addition of molasses is an effective silage additive in terms of stimulating lactic acid fermentation, reducing silage $\mathrm{pH}$, preventing clostridial fermentation and proteolysis, and generally limiting $\mathrm{OM}$ losses (Heinritzet al., 2012; Chen et al., 2014; Wang et al., 2017). Lactic acid is one of the most important indicators of fermentation in low DM silage, with desirable values $>30$ $\mathrm{g} \mathrm{kg}^{-1} \mathrm{DM}$. This acid content is not necessarily an indicator of successful fermentation in high DM silages, which typically undergo a lower level of fermentation (Cherney and Cherney, 2003).

Some recent studies have demonstrated that warm-season legumes need additives to improve their fermentation process, because if not, CP and WSC concentrations decrease, which result in higher NDF concentrations, with $\mathrm{pH}$ and butyrate concentrations relatively high, and lactate and VFA concentrations quite low (Foster et al., 2011). Contents of acetic acid increased slightly at 70 days of ensiling in $\mathrm{Tb} 1$ and $\mathrm{Tb} 2$ samples, but even so they remain as small amounts that do not detract the quality of silage. $\mathrm{Tb} 1$ and $\mathrm{Tb} 2$ concentrations were lower at 35 days, showing values below $1 \%$.

Above 2\%, undesirable fermentations occur, such as those resulting from the action of the Coliforme genus bacteria, heterofermentative lactic bacteria and Clostridic bacteria (Allen et al., 1995). Propionic and butyric acid were not detected in Tb1 samples, while at 70 days of ensiling in $\mathrm{Tb} 2$ samples higher values than $0.1 \%$ were found. This concentration classified this silage as bad quality. The two combinations of tagasaste (Tb1, Tb2) showed a good DM and OM content similar to the samples before ensiling (Table 5). In spite of degradation of protein that have taken place in the ensiling process, the crude protein content is relatively higher compared with fresh tagasaste, due to the addition of molasses in different concentrations.

It has been demonstrated that the nutritive value of ensiled legume forage is limited by the extensive protein degradation that occurs in many forages during ensiling (Albrecht and Muck, 1991). Proteolysis during fermentation results in extensive degradation of native plant proteins to non-protein N (NPN), which consists principally of ammonia $\mathrm{N}(\mathrm{NH} 3-\mathrm{N})$ (Ohshima and McDonald, 1978). Fiber values (NDF and ADF) and IVOM Digestibility were similar to those in fresh tagasaste with differences between $\mathrm{Tb} 1$ and $\mathrm{Tb} 2$ combinations $(p<$ $0.05)$, with better values in the combination with higher molasses concentration.

The fermentation characteristics of maralfalfa (MV1, MV2) after two periods of ensiling (35d, 70d) are given in Table 4. In the present study, addition of beet pulp and molasses to the ensiled maralfalfa allows to achieve the $\mathrm{pH}$ value under 4 and $\mathrm{NH} 3-\mathrm{N}$ content below $10 \%$, with an interesting content of lactic acid. The additives enabled the development of medium quality silage from forage of unsuitable characteristics. Silage $\mathrm{pH}$ is one of main factors that influence the extent of fermentation and silage quality of ensiled forage, as a low $\mathrm{pH}$ ensures that the forage is retained in a stable form (Wang et al., 2009). The molasses addition before ensiling increased WSC of ensiled forages, producing more substrates for $\mathrm{LAB}$, and promotes $\mathrm{LAB}$ propagation at the early stage of ensiling. This process results in a rapid increase in lactic acid and a drop in $\mathrm{pH}$, which inhibit activities of non-lactic acid bacteria and plant enzymes for proteolysis (Li et al., 2014). Molasses, a food byproduct of sugar beet and sugarcane production, is typically used as fermentable substrate for forage silage (Cao et al., 2010; Oni et al., 2014; Wang et al., 2017). Acetic acid was determined under $2 \%$ at 35 days ensiling and very slightly above this percentage at 70 days ensiling. But nevertheless, propionic and butyric acid were no detected at any period of study.

The addition of molasses and beet pulp improve the nutritive value of MV1 and MV2 silages at 35 and 70 days of ensiling (Table 5). Crude protein, IVOMD and energy values increased while fibre contents decreased significantly. This reduction in fibre fractions has been already reported for other tropical forages as cassava (Oni et al., 2014). The stability over time was considered acceptable as the values remain relatively constant throughout the conservation process.

Table 1. Ensilability characteristics of two experimental forages (tagasaste and maralfalfa).

\begin{tabular}{lccccccc}
\hline Fractions & $\begin{array}{c}\text { DM } \\
\mathbf{( \% )}\end{array}$ & $\begin{array}{c}\text { WSC } \\
\mathbf{( \% )}\end{array}$ & $\mathbf{B C}$ & $\mathbf{F R}$ & $\begin{array}{c}\text { Nitrite } \\
\mathbf{( p p m )}\end{array}$ & $\begin{array}{c}\text { Nitrate } \\
\mathbf{( p p m )}\end{array}$ \\
\hline $\mathrm{TB}$ & 40.75 & 3.22 & 107.78 & 43.14 & negative & 10 \\
$\mathrm{~Tb}$ & 33.86 & 3.88 & 130.02 & 36.25 & negative & ND \\
$\mathrm{MF}$ & 16.50 & 4.65 & 265.96 & 17.90 & negative & ND \\
$\mathrm{MV}$ & 12.24 & 4.65 & 357.27 & 13.28 & positive & ND \\
\hline
\end{tabular}

DM: dry matter; WSC: water soluble carbohydrates; BC: buffering capacity (meq $\mathrm{NaOH} \mathrm{kg}{ }^{-1} \mathrm{MS}$ ); FR: fermentability ratio. ND: Not detected. TB: Tagasaste including branches $>5 \mathrm{~mm}$; Tb: Tagasaste including branches $\leq 5 \mathrm{~mm}$. MF: Maralfalfa flowering stage; MV: Maralfalfa vegetative growth stage. 
Table 2. Chemical composition of two fractions of tagasaste (TB, Tb) and maralfalfa (MF, MV) without additives previous ensiling.

\begin{tabular}{lccccc}
\hline & \multicolumn{2}{c}{ Tagasaste } & & Maralfalfa & \\
\cline { 2 - 3 } \cline { 5 - 6 } \cline { 5 - 6 } & TB & Tb & & MF & MV \\
\hline DM (\%) & $40.75 \pm 0.85^{\mathrm{a}}$ & $33.86 \pm 0.75^{\mathrm{b}}$ & & $16.50 \pm 0.96^{\mathrm{b}}$ & $12.24 \pm 0.54^{\mathrm{a}}$ \\
OM (\% of DM) & $96.02 \pm 0.23$ & $95.44 \pm 0.54$ & & $86.99 \pm 0.15$ & $86.43 \pm 0.23$ \\
CP (\% of DM) & $12.98 \pm 0.32^{\mathrm{a}}$ & $17.30 \pm 0.47^{\mathrm{b}}$ & & $6.55 \pm 0.52^{\mathrm{a}}$ & $10.44 \pm 0.62^{\mathrm{b}}$ \\
NDF (\% of DM) & $64.51 \pm 0.69^{\mathrm{b}}$ & $52.65 \pm 0.98^{\mathrm{a}}$ & & $70.68 \pm 1.10^{\mathrm{a}}$ & $64.67 \pm 0.98^{\mathrm{b}}$ \\
ADF (\% of DM) & $38.04 \pm 0.47^{\mathrm{b}}$ & $26.58 \pm 0.32^{\mathrm{a}}$ & & $42.23 \pm 0.72^{\mathrm{b}}$ & $36.99 \pm 0.53^{\mathrm{a}}$ \\
IVOMD (\% of DM) & $43.81 \pm 0.34^{\mathrm{a}}$ & $55.56 \pm 0.48^{\mathrm{b}}$ & & $42.53 \pm 1.08^{\mathrm{a}}$ & $52.83 \pm 1.24^{\mathrm{b}}$ \\
GE (MJ/kg MS) & $19.43 \pm 0.07$ & $20.13 \pm 0.12$ & & $16.62 \pm 0.11$ & $16.27 \pm 0.06$ \\
UFL & $0.47 \pm 0.02^{\mathrm{a}}$ & $0.65 \pm 0.04^{\mathrm{b}}$ & & $0.45 \pm 0.02^{\mathrm{a}}$ & $0.61 \pm 0.03^{\mathrm{b}}$ \\
\hline
\end{tabular}

$\stackrel{\mathrm{a}-\mathrm{b}}{\mathrm{Dalues}}$ in the same row and within the same species without a common superscript letter are significantly different $(P<0.05)$.

DM: dry matter; OM: organic matter; CP: crude protein; NDF: neutral detergent fibre; ADF: acid detergent fibre; IVOMD: in vitro organic matter digestibility; GE: gross energy; UFL: milk forage units.

TB: Tagasaste including branches $>5 \mathrm{~mm}$; Tb: Tagasaste including branches $\leq 5 \mathrm{~mm}$.

MF: Maralfalfa flowering stage; MV: Maralfalfa vegetative growth stage

Table 3. Chemical composition comparison of tagasaste with additives before ensiling (Tb1, Tb2) with tagasaste without additives (Tb) and maralfalfa with additives before ensiling (MV1, MV2) with maralfalfa without additives (MV).

\begin{tabular}{|c|c|c|c|c|c|c|}
\hline & $\begin{array}{c}\text { Tagasaste } \\
\text { Tb }\end{array}$ & Tb1 & Tb2 & $\frac{\text { Maralfalfa }}{\text { MV }}$ & MV1 & MV2 \\
\hline DM (\%) & $33.86 \pm 0.75^{a}$ & $46.01 \pm 0.95^{b}$ & $41.78 \pm 0.45^{\mathrm{a}}$ & $16.50 \pm 0.96^{\mathrm{a}}$ & $31.56 \pm 0.59^{b}$ & $32.06 \pm 1.09^{\mathrm{b}}$ \\
\hline OM (\% of DM) & $95.44 \pm 0.54$ & $93.38 \pm 0.01$ & $93.0 \pm 0.01$ & $86.99 \pm 0.15$ & $89.82 \pm 0.03$ & $89.43 \pm 0.01$ \\
\hline CP (\% of DM) & $17.30 \pm 0.47$ & $11.69 \pm 0.16$ & $13.44 \pm 0.23$ & $6.55 \pm 0.52$ & $9.97 \pm 0.30$ & $10.60 \pm 0.33$ \\
\hline NDF (\% of DM) & $52.65 \pm 0.98^{a}$ & $28.37 \pm 0.28^{b}$ & $30.30 \pm 0.21^{b}$ & $70.68 \pm 1.10^{b}$ & $38.18 \pm 0.11^{\mathrm{a}}$ & $34.53 \pm 0.91^{\mathrm{a}}$ \\
\hline ADF (\% of DM) & $26.58 \pm 0.32$ & $16.90 \pm 0.16$ & $16.79 \pm 0.15$ & $42.23 \pm 0.72^{b}$ & $19.88 \pm 0.16^{\mathrm{a}}$ & $19.47 \pm 0.15^{\mathrm{a}}$ \\
\hline IVOMD (\% of DM) & $55.56 \pm 0.48^{a}$ & $72.92 \pm 0.92^{b}$ & $72.98 \pm 0.11^{b}$ & $42.53 \pm 1.08^{\mathrm{a}}$ & $68.58 \pm 0.42^{b}$ & $72.82 \pm 0.01^{b}$ \\
\hline GE (MJ/kg MS) & $20.13 \pm 0.12^{\mathrm{a}}$ & $17.02 \pm 0.03^{\mathrm{b}}$ & $16.98 \pm 0.09^{\mathrm{b}}$ & $16.62 \pm$ & $14.61 \pm 0.06$ & $14.59 \pm 0.08$ \\
\hline UFL & $0.65 \pm 0.04^{\mathrm{a}}$ & $0.92 \pm 0.01^{\mathrm{b}}$ & $0.92 \pm 0.01^{\mathrm{b}}$ & $0.45 \pm 0.02^{\mathrm{a}}$ & $0.85 \pm 0.01^{\mathrm{b}}$ & $0.91 \pm 0.01^{\mathrm{b}}$ \\
\hline
\end{tabular}

a-bValues in the same row and within the same species without a common superscript letter are significantly different $(p<0.05)$; DM: dry matter; OM: organic matter; CP: crude protein; NDF: neutral detergent fibre; ADF: acid detergent fibre; IVOMD: in vitro organic matter digestibility; GE: gross energy; UFL: milk forage units; Tb: Tagasaste including branches $\leq 5 \mathrm{~mm}$; Tb1: $23 \%$ molasses); Tb2: 17\% molasses; MV: Maralfalfa vegetative growth stage; MV1: 20\% molasses and $10 \%$ beet pulp; MV2: $23 \%$ molasses and $13 \%$ beet pulp.

Table 4. Fermentative parameters of tagasaste and maralfalfa with additives for 35 and 70 ensiling days.

\begin{tabular}{lccccc}
\hline & Samplingday & \multicolumn{2}{c}{ Tagasaste } & \multicolumn{2}{c}{ Maralfalfa } \\
\cline { 2 - 5 } & & Tb1 & Tb2 & MV1 & MV2 \\
\hline pH & 35 & $3.97 \pm 0.04$ & $3.91 \pm 0.02$ & $3.85 \pm 0.35$ & $3.96 \pm 0.04$ \\
& 70 & $4.09 \pm 0.03$ & $4.18 \pm 0.01$ & $3.97 \pm 0.03$ & $3.99 \pm 0.01$ \\
NH3-N (\% tot N) & 35 & $2.92 \pm 0.01$ & $3.00 \pm 0.35$ & $8.09 \pm 0.23^{\mathrm{b}}$ & $6.79 \pm 0.40^{\mathrm{a}}$ \\
& 70 & $3.82 \pm 0.22$ & $3.83 \pm 0.24$ & $8.59 \pm 0.21^{\mathrm{b}}$ & $7.43 \pm 0.05^{\mathrm{a}}$ \\
Lactic Acid (\% of DM) & 35 & $5.38 \pm 0.11^{\mathrm{b}}$ & $4.25^{\mathrm{a}} \pm 0.72$ & $5.75 \pm 1.40^{1}$ & $4.95 \pm 0.19^{1}$ \\
& 70 & $6.12 \pm 0.06$ & $5.99^{2} \pm 0.52$ & $8.41 \pm 0.44^{2}$ & $7.61 \pm 0.76^{2}$ \\
Acetic Acid (\% of DM) & 35 & $0.61 \pm 0.03$ & $0.96 \pm 0.06$ & $1.89 \pm 0.07$ & $1.48 \pm 0.22$ \\
& 70 & $1.23 \pm 0.16$ & $1.40 \pm 0.25$ & $2.07 \pm 0.21$ & $2.01 \pm 0.05$ \\
Propionic Acid (\% of DM) & 35 & 0 & 0 & 0 & 0 \\
& 70 & 0 & 0 & 0 \\
Butyric Acid (\% of DM) & 35 & 0 & 0 & 0 \\
& 70 & $0^{\mathrm{a}}$ & $0.13 \pm 0.01^{\mathrm{b} .2}$ & 0 \\
VFAs(\% of DM) & 35 & $0.61 \pm 0.03$ & $0.96 \pm 0.06$ & $1.89 \pm 0.07$ & $1.48 \pm 0.22$ \\
& 70 & $1.23 \pm 0.16$ & $1.53 \pm 0.21$ & $2.07 \pm 0.21$ & $2.01 \pm 0.05$ \\
\hline
\end{tabular}

Means within rows (a,b) and columns $(1,2)$ within the same species with different superscripts differ significantly at $p<0.05$; VFAs: Volatile fatty acids. Tb: Tagasaste including branches $\leq 5 \mathrm{~mm}$; Tb1: $23 \%$ molasses); Tb2: 17\% molasses. MV: Maralfalfa vegetative growth stage; MV1: 20\% molasses and $10 \%$ beet pulp; MV2: $23 \%$ molasses and 13\% beet pulp. 
Table 5. Chemical composition of tagasaste and maralfalfa with additives for 35 and 70 ensiling days.

\begin{tabular}{|c|c|c|c|c|c|}
\hline & \multicolumn{3}{|c|}{ Tagasaste } & \multicolumn{2}{|l|}{ Maralfalfa } \\
\hline & $\begin{array}{l}\text { Sampling } \\
\text { day }\end{array}$ & Tb1 & $\mathbf{T b 2}$ & MV1 & MV2 \\
\hline \multirow[t]{2}{*}{ DM (\%) } & 35 & $42.06 \pm 1.25$ & $40.52 \pm 4.10$ & $30.34 \pm 0.31^{b}$ & $35.59 \pm 2.54^{b}$ \\
\hline & 70 & $41.24 \pm 0.39$ & $36.08 \pm 3.75$ & $27.70 \pm 0.69^{b}$ & $30.46 \pm 0.36^{b}$ \\
\hline \multirow[t]{2}{*}{ OM (\% of DM) } & 35 & $92.68 \pm 0.21$ & $93.07 \pm 0.72$ & $89.29 \pm 0.38$ & $89.68 \pm 0.09$ \\
\hline & 70 & $92.02 \pm 0.24$ & $92.30 \pm 0.07$ & $88.52 \pm 0.14$ & $88.26 \pm 0.64$ \\
\hline \multirow[t]{2}{*}{ CP (\% of DM) } & 35 & $14.40 \pm 0.25$ & $13.22 \pm 0.43$ & $10.10 \pm 0.62^{b}$ & $10.31 \pm 0.12^{\mathrm{b}}$ \\
\hline & 70 & $14.28 \pm 0.02$ & $15.56 \pm 1.20$ & $10.56 \pm 0.01^{\mathrm{b}}$ & $11.53 \pm 0.79^{b}$ \\
\hline \multirow[t]{2}{*}{ NDF (\% of DM) } & 35 & $28.46 \pm 0.63$ & $32.09 \pm 9.90^{1}$ & $41.64 \pm 2.94^{\mathrm{a}}$ & $40.03 \pm 0.66^{\mathrm{a}}$ \\
\hline & 70 & $29.80 \pm 1.86^{\mathrm{a}}$ & $38.39 \pm 0.25^{\mathrm{b} 2}$ & $36.21 \pm 1.27^{\mathrm{a}}$ & $35.88 \pm 1.08^{\mathrm{a}}$ \\
\hline \multirow[t]{2}{*}{ ADF (\% of DM) } & 35 & $16.40 \pm 0.19^{\mathrm{a}}$ & $19.98 \pm 2.90^{\mathrm{b}}$ & $24.09 \pm 2.39^{\mathrm{a}}$ & $22.58 \pm 0.13^{\mathrm{a}}$ \\
\hline & 70 & $16.27 \pm 1.16^{\mathrm{a}}$ & $22.24 \pm 1.35^{b}$ & $22.18 \pm 0.31^{\mathrm{a}}$ & $21.78 \pm 0.57^{\mathrm{a}}$ \\
\hline \multirow[t]{2}{*}{ IVOMD (\% of DM) } & 35 & $73.05 \pm 0.23$ & $70.00 \pm 7.49^{2}$ & $66.44 \pm 1.72^{b}$ & $68.18 \pm 1.06^{\mathrm{b}}$ \\
\hline & 70 & $73.91 \pm 2.08^{b}$ & $63.44 \pm 0.81^{\mathrm{a} 1}$ & $67.48 \pm 2.15^{b}$ & $69.88 \pm 1.71^{b}$ \\
\hline \multirow[t]{2}{*}{ GE (MJ/Kg MS) } & 35 & $18.27 \pm 0.06$ & $18.10 \pm 0.09$ & $15.57 \pm 0.09$ & $15.94 \pm 0.12$ \\
\hline & 70 & $18.01 \pm 0.13$ & $18.23 \pm 0.02$ & $15.18 \pm 0.10$ & $15.21 \pm 0.03$ \\
\hline \multirow[t]{2}{*}{ UFL } & 35 & $0.92 \pm 0.01^{\mathrm{b}}$ & $0.87 \pm 0.12^{\mathrm{a} 2}$ & $0.82 \pm 0.03^{b}$ & $0.84 \pm 0.02^{b}$ \\
\hline & 70 & $0.93 \pm 0.03^{b}$ & $0.77 \pm 0.01^{\mathrm{a} 1}$ & $0.83 \pm 0.03^{b}$ & $0.87 \pm 0.03^{b}$ \\
\hline
\end{tabular}

Means within rows $(\mathrm{a}, \mathrm{b})$ and columns $(1,2)$ within the same species with different superscripts differ significantly at $p<0.05$. DM: dry matter; OM: organic matter; CP: crude protein; NDF: neutral detergent fibre; ADF: acid detergent fibre; IVOMD: in vitro organic matter digestibility; GE: gross energy; UFL: milk forage units. Tb: Tagasaste including branches $\leq 5 \mathrm{~mm}$; Tb1: $23 \% \mathrm{molasses}$; Tb2: 17\% molasses. MV: Maralfalfa vegetative growth stage; MV1: 20\% molasses and $10 \%$ beet pulp; MV2: $23 \%$ molassesand 13\% beet pulp.

Conclusion: Tagasaste showed an acceptable aptitude for ensiling when molasses was added to the raw material in order to improve WSC content. Moreover, a good fermentative composition and low changes in nutritive value during silage were detected. Likewise, the protein content and IVOMD enhance their values with molasses addition, contributing to preserve silage from undesirable fermentation by increasing significantly the amount of lactic acid. Meanwhile, maralfalfa showed an unsuitable aptitude for ensiling needing specific additives to improve not only sugar content but also dry matter percentage. However, additives enabled medium quality silage improving nutritive value. Besides, further studies are required in order to assess palatability and to observe feed intake. In addition, the influence of forage silage diets on milk and cheese production must be checked. Maralfalfa and tagasaste are fodder that can be used to make medium quality silage, improving the ensilability characteristics by using certain additives. Nevertheless, it would be interesting to check different fermenting starting material to avoid as much as possible the use of additives.

Acknowledgements: This work was supported by the EU Transnational Cooperation Programme (Project MAC/3/C188 GANAFRICA) with FEDER funds (European Union).

\section{REFERENCES}

Aksu, T., E. Baytok, and D. Bolat (2004). Effects of a bacterial silage inoculant on corn silage fermentation and nutrient digestibility. Small Rumin. Res. 55: 249-252.

Álvarez, S., M.Fresno, N. Darmanin, H. Briggs,P. Méndez, andN. Castro (2007). Forage assessment for the improvement of milk production in goats. J. Anim. Vet. Adv. 6: 94-98.

Álvarez, S., M. Fresno, and P. Méndez (2008). Influence of the diet based on autochthonous subhumid forages from Canary Islands over the milk and cheese production of the Palmera goat breed. Proc. 22th General Meeting EGF, Biodiversity and Animal Feed. Future Challenges for Grassland Production. 72.

Albrecht, K.A., and K.A. Beauchemin (2003). Alfalfa and other perennial legume silage. In: Buxton, D.R., Muck, R.E. and Harrison J.H., editors. Silage Science and Technology. Agronomy Monograph 42. Amer. Soc. Agronomy, Madison, WI (USA), 633-664.

Albrecht, K.A, and R.E. Muck (1991). Proteolysis in ensiled forage legumes that vary in tannin concentration. Crop Sci. 31:464-469. 
Allen, M., S. Ford, J. Harrison, C. Hunt,J. Lauer, R. Muck, and S. Soderlund (1995).Corn silage management in: Roth G., and Undersander D., editors. Corn silage production, management and feeding. Amer Soc Agronomy; Madison, WI (USA).

AOAC. (1984) Official Methods of Analysis. 14th ed. Association of Official Analytical Chemistry; Arlington, VG (USA).

Ashbell, G., and Z.G. Weinberg (2000) Paper 7.0: Silage from tropical cereals and forage crops. In: Mannetje, L., editor.Silage making in the tropics with particular emphasis on the smallholder. Plant Production and Protection paper 161. FAO editions; Rome.

Cao, Y., T. Takahashi, K. Horiguchi and N. Yoshida (2010) Effect of adding lactic acid bacteria and molasses on fermentation quality and in vitro ruminal digestion of total mixed ration silage prepared with whole crop rice. Grassl. Sci. 56: 1925.

Chen, L., G. Guo, X. Yuan, M. Shimojo, C. Yu, and T. Shao (2014). Effect of applying molasses and propionic acid on fermentation quality and aerobic stability of total mixed ration silage prepared with whole-plant corn in Tibet. AsianAustralas. J. Anim. Sci. 27: 349-356.

Cherney, J.H., and D.J.R. Cherney (2003) Assessing Silage Quality. In: Buxton, D.R., Muck, R.E., and Harrison J.H., editors.Silage Science and Technology. Agronomy Monograph 42.AmerSoc Agronomy, Madison, WI (USA), 141-198.

Cowan, T. (2000) Paper 4.0: Use of ensiled forages in large scale animal production systems. In: Mannetje, L., editor. Silage making in the tropics with particular emphasis on the smallholder. Plant Production and Protection paper 161. FAO editions, Rome.

Dunière, L., J. Sindou, F. Chaucheyras-Durand, I. Chevallier, and D. Thévenot-Sergentet (2013) Silage processing and strategies to prevent persistence of undesirable microorganisms. Anim. Feed Sci. Technol. 182: 1-15.

Ferrari Junior, E., V.T. Paulino, R.A. Possenti, and T.L. Lucenas (2009) Additives in silage of paraiso grass (Pennisetum hybridum cv. paraiso). Arch. Zootec. 58: 185-194.

Foster, J.L., Carter, J.N., L.E. Sollenberger, A.R. Blount, R.O. Myer, M. K. Maddox, S.C. Phatak, and A.T. Adesogan (2011) Nutritive value, fermentation characteristics, and in situ disappearance kinetics of ensiled warm-season legumes and bahiagras. J. Dairy Sci. 94: 2042-2050.

González-Rodríguez, A.M., A. Martin-Olivera, D. Morales, and M.S. Jiménez (2005). Physiological response of tagasaste to a progressive drought in its native environment on the Canary Islands. Environ. Exp. Bot. 53(2): 195-204.

Heinritz, N., D. Martens, P. Avila, and S. Hoedtke (2012) The effect of inoculant and sucrose addition on the silage quality of tropical forage legumes with varying ensilability. Anim. Feed Sci. Technol. 17: 201-210.

Henderson, N. (1993) Silage additives. Anim. Feed Sci. Technol.45: 35-56.

Heuzé, V., Thiollet, H., Tran, G., Hasoun, P., Bastionelli, D., and F. Lebas (2017). Tagasaste (Cytisusproliferus). Feedipedia (INRA, CIRAD, AFZ and FAO). https://www.feedipedia.org/node/310.

INRA (1981) Prévision de la valeur nutritive des aliments des ruminants. INRA publications; Versalles (France).

Li, M., Z. Xuejuan, Z. Hanlin, H. Guanyu, and C. Yimin(2014) Effects of sucrose, glucose, molasses and cellulase on fermentation quality and in vitro gas productionof king grass silage. Anim. Feed Sci. Technol. 197: 206-212.

Martínez-Fernández, A., A. Soldado, B. de la RozaDelgado, F. Vicente, M.A. Gonzalez-Arrojo, and A. Argamenteria (2013) Modelling a quantitative ensilability index adapted to forages from wet temperate areas. Span. J. Agric. Res. 11: 455-462.

Martínez-Fernández, A., A. Argamentería, and B. De la Roza (2014) Manejo de forrajes para ensilar. SERIDA publications; Asturias (Spain).280 p.

McDonald, P., A.R. Henderson, and S.J.E. Heron (1991) The Biochemistry of Silage. 2nd Ed. Chalcombe Publications; Marlow (England)340 p.

Méndez, P., and S. Álvarez (2014) El tagasaste. Agropalca 25: 31 .

Ohshima, M.,and P. McDonald (1978)A review of the herbages in nitrogenous compounds in herbage during ensiling. J. Sci. Food Agric. 29: 497-505.

Oni, A.O., O.S. Sowande, O.O. Oni, R.Y. Aderinboye, P.A. Dele, V.O. Ojo, O.M. Arigbede, and C.F. Onwuka (2014) Effect of additives on fermentation of cassava leaf silage and ruminal fluid of west african dwarf goats. Arch. Zootec. 63: 449-459.

Rezende, A.A., L.A. Pascoal, E.H. Van Cleef, J.S. Gonçalves, N. Olszevski, and A.P. Bezerra (2011) Chemical composition and fermentative characteristics of sugar cane silages containing babassu meal. Arch. Zootec. 60: 1031-1039.

Riveros, E., and A. Argamentería (1987) Métodos enzimáticos de la predicción de la digestibilidad in vivo de la materia orgánica de forrajes. I. Forrajes verdes. II. Henos. III Ensilados y pajas. Avances en Producción Animal 1: 49-75.

Rooke, J., and R. Hatfield (2003) Biochemistry of Ensiling. In: Buxton, D.R., Muck, R.E., and 
Harrison J.H., editors.Silage Science and Technology. Agronomy Monograph 42, Amer. Soc. Agronomy; Madison, WI (USA).95-139.

Silva, T.C., P.A. Dantas, J.R. Dórea, E.M. Santos, A.M. Zanine, and O.G. Pereira (2011) Microbial populations, fermentation profile and chemical composition of elephant grass silages with jackfruit. Arch. Zootec. 60: 247-255.

Teles-Rêgo, M.M., J.N. Miranda-Neiva, M.A. BorgesCavalcante, M.J. Duarte-Candido, R. HerculanoClementino, and J Restle (2010) Bromatological and fermentative characteristics of elephant grass silages with the addition of annato by-product. Rev. Bras. Zoot. 39: 1905-1910.

Titterton, M., and F.B. Bareeba (2000) Paper 4.0: Grass and legume silages in the tropics. In: Mannetje, L., editor. Silage making in the tropics with particular emphasis on the smallholder. Plant Production and Protection paper 161. FAO editions; Rome.
Van Soest, P.J., J.B. Robertson, and B.A. Lewis (1991) Methods of dietary fiber, neutral detergent fiber and non-starch polysaccharides in relation to animal nutrition. J. Dairy Sci.74: 3583-3597.

Wang, J., J.Q. Wang, H. Zhou, and T. Feng (2009) Effects of addition of previously fermented juice prepared from alfalfa on fermentation quality and protein degradation of alfalfa silage. Anim. Feed Sci. Technol.151: 280-290.

Wang, J., L. Chen, X. Yuan, G. Guo, J. Li, Y. Bai, and T. Shao (2017) Effects of molasses on the fermentation characteristics of mixed silage prepared with rice straw, local vegetable byproducts and alfalfa in Southeast China. J. Integr. Agric. 16(3): 664-670.

Zanine, A.M., E.M. Santos, D.J. Ferreira, L.B. Pinto, and O.G. Pereira (2007) Fermentative characteristics and chemical composition of elephant grass silages with or without lactobacillus plantarum and wheat meal isolated or in association. Ciênc. Anim. Bras. 8: 609-62. 